\title{
DETERMINATION OF SELECTIVITY AND MASS TRANSFER IN LIQUID-PHASE EXTRACTION FOR BUTYL GLYCOL-WATER-ISOPROPYL ETHER SYSTEM
}

\author{
A.A.Hasanov \\ Azerbaijan State University of Oil and Industry \\ alakbar48-48@mail.ru
}

Received 21.04.2020

Accepted 22.07.2020

\begin{abstract}
The problems of phase equilibrium, the equilibrium distribution of a component between phases are considered, and the distribution coefficient is determined in two versions. A formula for determining the selectivity coefficient is obtained, equations relating the compositions of coexisting phases, by equating the activities in these phases, Margules constants are found. Based on the given content of the components, the numerical values of $A_{A S}$ (Margules constant for $\mathrm{A}$ component in solvent $\mathrm{S}$ ) and $A_{S A}$ (Margules constant for S component in solvent A) were found Using the Margules equation for ternary systems, the activity coefficients of components A and B are determined in two phases. The experimentally obtained values of the molar fractions of each of the three components, responsible to different points of the binodal curve, the corresponding activity coefficients of component $\mathrm{B}$, and also calculated on these coefficients of the activity values.
\end{abstract}

Keywords: equilibrium, coefficient, extraction, component, equation, activity, selectivity.

doi

\section{Introduction}

Accurate knowledge of the equilibrium relationships is essential for quantifying extraction processes. The required amount of extractant is determined by the equilibrium data. The driving force for mass transfer is also determined by thermodynamic considerations. Since a very important requirement is the formation of two stable liquid phases, the dissolved components of at least one phase should sharply differ in behavior from the components of an ideal mixture. Accordingly, an extractant with high selectivity with respect to one of the components of the initial solution should be a mixture of substances in which the remaining components have high activity coefficients and are removed from the extractant when equilibrium is reached. Therefore, at obtaining quantitative dependences expressing the phase equilibrium in liquid-liquid systems, have to use the method of properties of non-ideal solutions [1].

\section{Experimental research and obtained results}

The equilibrium distribution of component $\mathrm{B}$ between two liquid phases takes place at its activities as in both phases are equal

$$
a_{\mathrm{B}}^{\prime}=a_{\mathrm{B}}^{\prime \prime}
$$

or in the case of introducing the activity coefficient $\gamma$ :

$$
K=\frac{x_{B}}{x_{\mathrm{B}^{\mathrm{K}^{\prime}}}}=\frac{\gamma_{\mathrm{B}^{\prime \prime}}}{\gamma_{\mathrm{B}^{\prime}}},
$$

where $K$ is the distribution coefficient; $x$ is the mole fraction of the component in the phase.

The equation applicable for each of the three components of the ternary system. In this case, however, let us consider the distribution of component B between insoluble liquids, and the phase with index ' is an almost pure component $\mathrm{S}$, and the phase with index " - almost pure component A. Then $x_{B}{ }^{\circ}$ is the activity coefficient of component B in the binary system AS, $\gamma_{B^{\prime \prime}}-$ is the activity coefficient of component B in the binary system AB. If the amount of component $\mathrm{B}$ in each of the phases is very small, the distribution coefficient is related to the constants A in the Margules or Van Laar equations by the following relationship [2]:

$$
\lg K=\mathrm{A}_{\mathrm{BA}}-\mathrm{A}_{\mathrm{BS}} \text {, }
$$


where, $\mathrm{A}_{\mathrm{BA}}$ - Margules constant of $\mathrm{B}$ component in water; $A_{B S}-$ Margules constant of $B$ component in isopropyl ether.

The values of like constants are given in the literature; they can be used to determine the phase equilibrium in systems for which lack experimental data.

If the mutual solubility of components A and $S$ is to be taken into account at calculating the binodal curve in the triangular diagram, the condition of equality of activities at equilibrium must be satisfied for each of the three components. In principle, this is possible, although also requires rather lengthy calculations from the known expressions for the activity coefficients of the components in three-component solutions. In this case, it is necessary that not only the numerical values of the six binary constants, but also the values of the triple constants be known. Calculations are performed by the method of successive approximations, selecting six concentrations of components (in mole fractions) for two phases; these concentrations must satisfy three equations of activities and two equations in which the mole fractions are summed up and equated to one.

A more simpler and limitedly suitable, but of practical importance method of calculation is based on determining the position of the equilibrium chords connecting the branches of the binodal curve constructed by the experimental points. So, if the values $x_{A}, x_{B}, x_{S}$ are known along the entire binodal curve, but the corresponding to them points $x_{A}^{\prime}, x_{B}^{\prime}, x_{S}^{\prime}$ and $x_{A}^{\prime \prime}, x_{B}^{\prime \prime}, x_{S}^{\prime \prime}$ under the ends equilibrium chords are not known, they can be determined in a simple way. For this, when calculating the equilibrium, it is necessary to know the value of the selectivity coefficient (selectivity) $\beta$ [3]:

$$
\beta=\frac{x_{\mathrm{BS}}}{x_{\mathrm{AS}}} \cdot \frac{x_{\mathrm{AA}}}{x_{\mathrm{BA}}} .
$$

The greater the $\beta$ value, the more selective the extractant is when interacting with components $\mathrm{A}$ and $\mathrm{B}$. In the equation, $x_{B S}$ and $x_{B A}$ are the mole fractions of component $\mathrm{B}$ in the phase enriched in the extractant (extract) and in the phase enriched in component B (raf- finate); $x_{A S}$ and $x_{\mathrm{AA}}$ are the mole fractions of component $\mathrm{A}$ in the same phases.

To determine the selectivity coefficient, it is necessary to calculate the Margules constants for the system water (A) - isopropyl ether (S). Using this equation, it is possible to obtain formulas for the binding compositions of the coexisting phases by equating the activities in these phases. Solving this equation with respect to the Margules constant A [4], we obtain:

$$
\begin{gathered}
\mathrm{A}_{\mathrm{SA}}=\frac{\lg \left(x_{\mathrm{AS}} / x_{\mathrm{AA}}\right)}{2\left(\frac{\mathrm{A}_{\mathrm{SA}}}{\mathrm{A}_{\mathrm{AS}}}-1\right)^{\mathrm{M}-2}\left(\frac{\mathrm{A}_{\mathrm{SA}}}{\mathrm{A}_{\mathrm{AS}}}-1\right)^{\mathrm{N}}}, \\
\frac{\mathrm{A}_{\mathrm{AS}}}{\mathrm{A}_{\mathrm{SA}}}=\frac{2(\mathrm{M}-\mathrm{N}) \lg \left(x_{\mathrm{SS}} / x_{\mathrm{SA}}\right)+(\mathrm{W}-2 \mathrm{Z}) \lg \left(x_{\mathrm{AS}} / x_{\mathrm{AA}}\right)}{2(\mathrm{~W}-\mathrm{Z}) \lg \left(x_{\mathrm{AS}} / x_{\mathrm{AA}}\right)+(\mathrm{M}-2 \mathrm{~N}) \lg \left(x_{\mathrm{SS}} / x_{\mathrm{SA}}\right)},
\end{gathered}
$$

where

$$
\begin{aligned}
& M=x_{\mathrm{SA}}^{2}-x_{\mathrm{SS}}^{2}, \quad N=x_{\mathrm{SA}}^{3}-x_{\mathrm{SS}}^{3}, \\
& W=x_{\mathrm{AA}}^{2}-x_{\mathrm{AS}}^{2}, \quad Z=x_{\mathrm{AA}}^{3}-x_{\mathrm{AS}}^{3} .
\end{aligned}
$$

Substituting the values $x_{\mathrm{AS}}=0.131, x_{\mathrm{SS}}=$ $0.8679, x_{\mathrm{SA}}=0.01738, x_{\mathrm{AA}}=0.9826$, obtained on the basis of a given content of components (in mass fractions), are found from the equations (1) and (2) the following numerical values $A_{\mathrm{AS}}$ and $A_{\mathrm{SA}}$ (the first index refers to the component, the mole fraction of which is specified, the second index - to the component from basically consists of a phase) [5]:

$$
\frac{A_{\mathrm{AS}}}{A_{\mathrm{SA}}}=0.6323, A_{\mathrm{AS}}=1.00, A_{\mathrm{SA}}=1.60 .
$$

When we calculating using the Van Laar equations for the same pair of components and the same conditions, obtained:

$$
\frac{A_{\mathrm{AS}}}{A_{\mathrm{SA}}}=0.565, A_{\mathrm{AS}}=1.03, A_{\mathrm{SA}}=1.79 .
$$

The values of six binary constants were then substituted into the Margules equation for ternary systems in order to determine the activity coefficients of components $\mathrm{A}$ and $\mathrm{B}$ in two liquid phases at compositions corresponding to the experimentally determined binodal curve. The following equations were obtained [6]: 
$\lg \not \zeta=x_{\mathrm{A}}^{2}\left[A_{\mathrm{BA}}+2 x_{\mathrm{B}}\left(A_{\mathrm{AB}}-A_{\mathrm{BA}}\right)\right]+x_{\mathrm{S}}^{2}\left[A_{\mathrm{BS}}+2 x_{\mathrm{B}}\left(A_{\mathrm{SB}}-A_{\mathrm{BS}}\right)\right]+x_{\mathrm{A}} x_{\mathrm{S}}[1 / 2]\left(A_{\mathrm{AB}}+A_{\mathrm{BA}}-A_{\mathrm{AS}}-A_{\mathrm{SA}}\right)+$ $+x_{\mathrm{B}}\left(A_{\mathrm{AB}}-A_{\mathrm{BA}}-A_{\mathrm{BS}}\right)+\left(x_{\mathrm{A}}-x_{\mathrm{S}}\right)\left(A_{\mathrm{AS}}-A_{\mathrm{SA}}\right)$,

$\lg Y_{A}=x_{S}^{2}\left[A_{A S}+2 x_{B A}\left(A_{S A}-A_{A S}\right)\right]+x_{B}^{2}\left[A_{A B}+2 x_{A}\left(A_{B A}-A_{A B}\right)\right]+x_{S} x_{B}[1 / 2]\left(A_{A S}+A_{S A}+A_{A B}+A_{B A}-A_{S B}-A_{B S}\right)+$ $+x_{A}\left(A_{S A}-A_{A S}+A_{B A}-A_{A B}\right)+\left(x_{S}-x_{B}\right)\left(A_{S B}-A_{B S}\right)-\left(1-2 x_{A}\right) C^{0}$

The experimental value of the constant $\mathrm{C}^{0}$ is unknown, but according to Colborn the value $\mathrm{C}^{0}$ can be taken equal to zero.

Table 1 shows the experimentally obtained values of the molar fractions of each of the three components corresponding to different points of the binodal curve, the corresponding activity coefficients of component $\mathrm{B}$, as well as those calculated from these coefficients [7].

The compositions at the ends of the equilibrium chords were found from the graph of the dependence of the activity of component $\mathrm{B}$ in phases enriched in $\mathrm{A}$ and $\mathrm{S}$ on the mole frac-

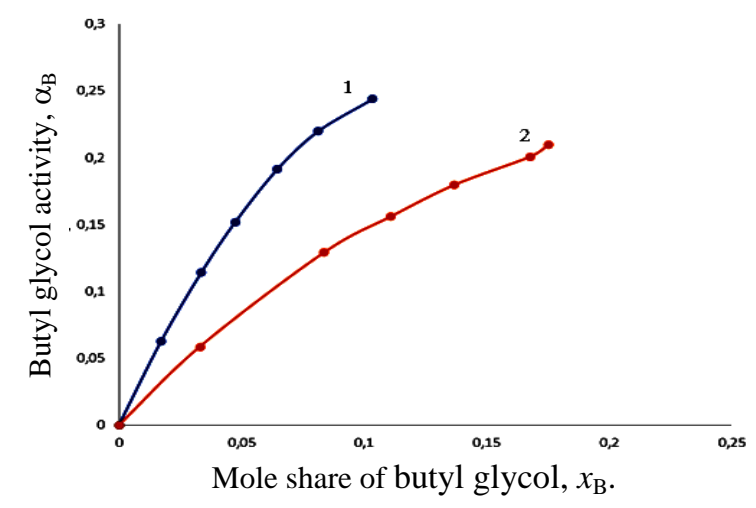

tion $x_{\mathrm{B}}$ of component B (Figure 1). The chord of equilibrium connects points of the same activity; these points can be found by graphical interpolation [8].

In Table 2 there are compared the experimental and calculated data for the points lying on the equilibrium chord.

In Figure 2 compares the experimental and calculated values of the selectivity coefficient $\beta$. The latter were determined by the equation:

$$
\beta_{\mathrm{BA}}=\frac{x_{\mathrm{BS}} / x_{\mathrm{AS}}}{x_{\mathrm{BA}} / x_{\mathrm{AA}}}=\frac{v_{\mathrm{AS}}}{v_{\mathrm{BS}}} \cdot \frac{v_{\mathrm{AB}}}{v_{\mathrm{AA}}}
$$

Fig. 1. Calculated values of the activities of butyl glycol in the butyl glycol-waterisopropyl ether system: 1 - layer enriched with water, 2 - layer isopropyl ether enriched.

Table 1. Calculation of activities

\begin{tabular}{|l|l|l|l|l|}
\hline \multicolumn{2}{|c|}{ Binodal Curve Coordinates } & \multicolumn{2}{c|}{ Calculated values } \\
\hline \multicolumn{1}{|c|}{$\boldsymbol{x}_{\boldsymbol{A}}$ (water) } & \multicolumn{1}{|c|}{$\boldsymbol{x}_{\bar{B}}$ (butyl glycol) } & $v_{\mathrm{B}}$ & $a_{B}$ \\
\hline \multicolumn{2}{|c|}{ Layer, water-enriched } & & \\
\hline 0.983 & 0.01738 & 0 & 3.91 & 0 \\
\hline 0.966 & 0.01772 & 0.01718 & 3.66 & 0.0628 \\
\hline 0.947 & 0.0194 & 0.0335 & 3.40 & 0.1140 \\
\hline 0.932 & 0.0219 & 0.0473 & 3.21 & 0.1517 \\
\hline 0.909 & 0.0263 & 0.0645 & 2.97 & 0.1914 \\
\hline 0.886 & 0.0335 & 0.0812 & 2.71 & 0.220 \\
\hline 0.847 & 0.0496 & 0.1034 & 2.36 & 0.244 \\
\hline \multicolumn{7}{|c|}{ Layer, isopropyl ether enriched } & & \\
\hline 0.1321 & 0.8679 & 0 & 1.915 & 0 \\
\hline 0.1520 & 0.815 & 0.0330 & 1.775 & 0.0586 \\
\hline 0.2055 & 0.711 & 0.0837 & 1.543 & 0.1291 \\
\hline 0.2545 & 0.634 & 0.1110 & 1.405 & 0.1560 \\
\hline 0.294 & 0.569 & 0.1368 & 1.312 & 0.1795 \\
\hline 0.396 & 0.437 & 0.1678 & 1.196 & 0.2007 \\
\hline 0.522 & 0.303 & 0.1754 & 1.196 & 0.2098 \\
\hline
\end{tabular}


Table 2. Comparison of experimental and calculated conjugate equilibrium compositions of phases. System water (A) butyl glycol, (B) - isopropyl ether (S) at $20^{\circ} \mathrm{C}$

\begin{tabular}{|c|c|c|c|}
\hline \multirow{2}{*}{$\begin{array}{c}\text { Layer, } \\
\text { water-enriched }\end{array}$} & \multicolumn{3}{|c|}{$\begin{array}{c}\text { Layer, } \\
\text { isopropyl ether enriched }\end{array}$} \\
\hline \multirow{3}{*}{$x_{B A}(\mathrm{eks})}$. & $x_{B S}(\mathrm{eks})$ & 0 & $x_{B S}$ (value.) \\
\cline { 3 - 4 } & & $\begin{array}{c}\text { according to Van Laar } \\
\text { equations }\end{array}$ & $\begin{array}{c}\text { according to the equations of our } \\
\text { proposed }\end{array}$ \\
\hline 0 & 0 & 0.038 & 0 \\
\hline 0.01718 & 0.0330 & 0.076 & 0.036 \\
\hline 0.0335 & 0.0837 & 0.110 & 0.106 \\
\hline 0.0473 & 0.1110 & 0.156 & 0.145 \\
\hline 0.0645 & 0.1368 & 0.183 & 0.186 \\
\hline 0.0812 & 0.1678 & - & 0.226 \\
\hline 0.1034 & 0.1754 & & \\
\hline
\end{tabular}

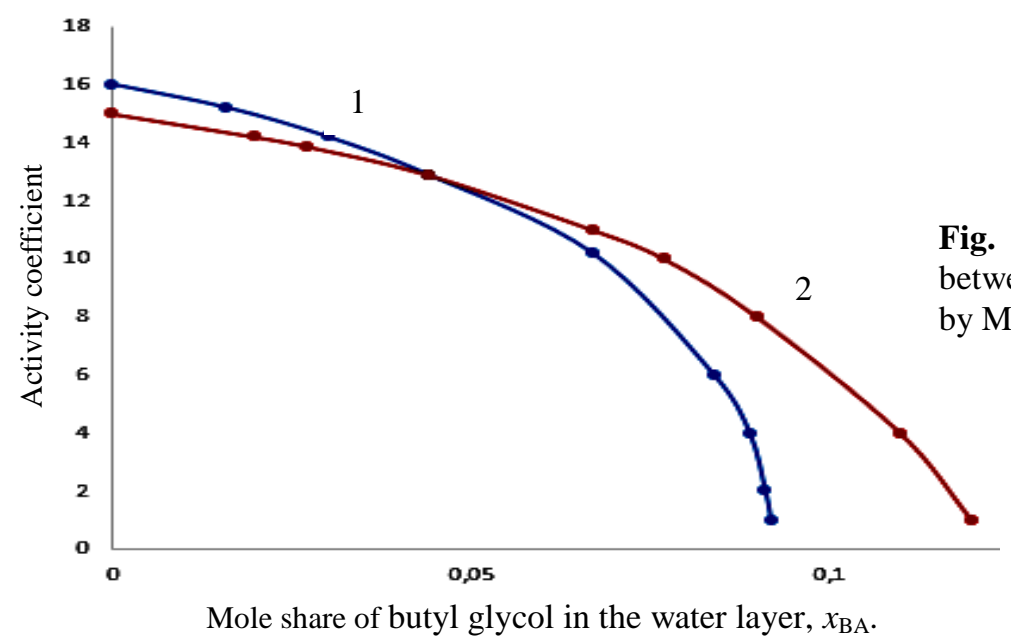

Table 3. Coefficients of molecular diffusion, distribution of components, mass efficiency and mass transfer

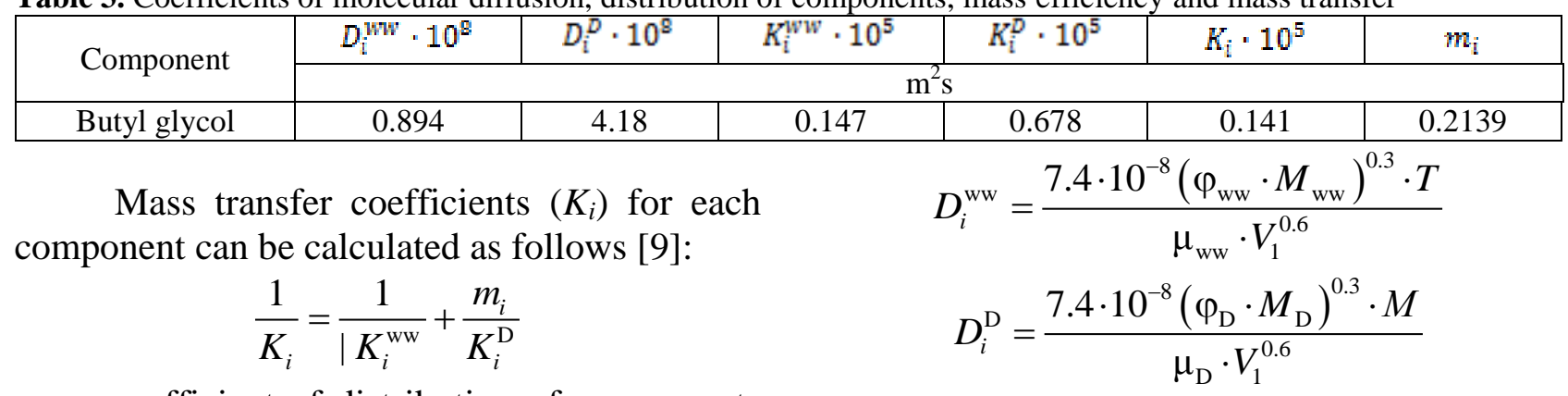

$m_{i}$ - coefficient of distribution of components in phases and is determined from the equilibrium equation; $K_{i}^{\mathrm{ww}}$ and $K_{i}^{\mathrm{D}}-$ mass transfer coefficients of the $i$-th component, respectively, in waste water and dispersed phase, we write as

$$
K_{i}^{\mathrm{ww}}=\frac{2 \pi^{2} D_{i}^{\mathrm{ww}}}{3 d_{k}} \quad K_{i}^{\mathrm{D}}=\frac{2 \pi^{2} D_{i}^{\mathrm{D}}}{3 d_{k}}
$$

Here $D_{i}^{W W}$ and $D_{i}^{D}$ are the coefficients of molecular diffusion of components in waste water and isopropyl ether, respectively [10]:
Fig. 2. Equilibrium distribution of butyl glycol by Margules, 2 - calculated by us. where $\varphi_{w w}$ and $\varphi_{D}$ are association factors in waste water and dispersed phase $\left(\varphi_{\mathrm{ww}}=2.6, \varphi_{\mathrm{D}}=1.0\right) ; T$ is an absolute temperature equal to $293 \mathrm{~K} ; M_{\mathrm{ww}}$ and $M_{\mathrm{D}}-$ molecular weights of waste water and dispersed phase $\left(M_{\mathrm{ww}}=18, M_{\mathrm{D}}=102\right)-$ molar volumes of components, $\mathrm{cm}^{3} / \mathrm{mol}\left(V_{1}=111.0\right.$, $\left.V_{2}=185.0, V_{3}=61, V_{4}=125.6\right)$.

The results of calculating the coefficients of molecular diffusion, distribution of components, mass transfer and mass transfer are shown in Table 3. 


\section{Conclusion}

Equations for determining the distribution coefficient are proposed and its values are determined.

Formulas for deducting the selectivity coefficient are obtained.

Equations were found connecting the compositions of the coexisting phases by equating the activities in these phases and Margules' constants.

Based on the specified content of the components, the numerical values of the activity coefficients of the components with respect to the extractant are determined.

The experimentally obtained values of the molar fractions of each of the three components, corresponding to different points of the binodal curve, are given.

A comparison of the experimental and calculated conjugate equilibrium compositions of the phases is presented, where the calculated data completely coincide with the experimental ones.

The experimentally obtained values of the molar fractions of each of the three components corresponding to different points of the binodal curve, the corresponding activity coefficients of component $\mathrm{B}$, as well as the activity values calculated from these coefficients are given.

\section{References}

1. Shervud T, Pigford R., Uilki Ch. Massoperedacha. M.: Himiia, 1982. 695 s.

2. Ziulkovskii Z. Zhidkostnaia ekstraktciia v himicheskoi promyshlennosti. L.: Goshimizdat, 1963. $480 \mathrm{~s}$.

3. Brounshtein B.N., Shchegolev V.V. Gidrodinamika, masso- i teploobmen $\mathrm{v}$ kolonnykh apparatakh. L.: Himiia, 1988. $336 \mathrm{~s}$.

4. Romankov P.G., Frolov V.F. Massoobmennye protcessy himicheskoi tekhnologii. L.: Himiia, 1990. $384 \mathrm{~s}$.

5. Zhidkostnaia ekstraktciia (teoriia i praktika). Pod. red. A.G.Kasatkina. M.: Gos.nauchno. tekhn. izdvo. him. lit. 1958. $155 \mathrm{~s}$.

6. Kovalev Iu.N., Kogan S.E. Mezhfazovaia poverkhnost $\mathrm{v}$ sistemakh zhidkost pri mehanicheskom peremeshivanii. Protcessy zhidkostnoi ekstraktcii i emosorbsii. Pod red. P.G.Romanova. L.: Himiia, 1966. $43 \mathrm{~s}$

7. Treibol R. Zhidkostnaia ekstraktciia. M.: Himiia, 1966. $724 \mathrm{~s}$.

8. Dytnerskii Iu.I. Protcessy i apparaty himicheskoi tekhnologii. M.: Himiia, 1995. $768 \mathrm{~s}$.

9. Gasanov A.A. Liquid extraction treatment of wastewaters at paint and varnish production facilities using the spray column. Water Chem. Technol. 2016. 38. No 4. P. 224-231.

10. Gasanov A.A, Suleimanov G.Z., Kelbaliev G.İ. Liquid-phase extraction treatment of wastewater of paint and varnish production facilities in the extractor with mixer. J. Water Chem. And Technol. 2016. V. 38. No 6. P. 336-341.

\section{BUTILQLIKKOL-SU-IZOPROPIL EFIRINDӘN İBARəT SISTEMIN MAYE FAZALI EKSTRAKSIYYADA SELEKTIVLIK VӘ KÜTLӘÖTÜRMӘ ӘMSALLARININ TəYINI}

\section{Ә.A.Həsənov}

Fazaların tarazlıq problemi geniş təhlil olunmuş, komponentin fazalar arası paylanması, paylanma əmsalının qiyməti iki variantda təyin edilmiş, selektivlik əmsalı, mövcud fazaların tərkibləri arasındakı əlaqəni göstərən tənliklər, fazalarda aktivliklərin bərabərləşdirilməsi əsasında Marqules sabiti hesablanmıșdır. Komponentlərin miqdarına əsasən $\mathrm{A}_{\mathrm{AS}}$ və $\mathrm{A}_{\mathrm{SA}}$ (birinci indeks paylanan komponentə, ikinci indeks isə fazanı təşkil edən komponentə aiddir) əmsallarının ədədi qiymətləri hesablanmışdır. Marqules tənliyinə əsasən üçlü sistem üçün A və B komponentlərinin hər iki fazada aktivlik əmsalları, binodal əyriyə uyğun hər üç komponentin mol payları, B komponentinin aktivlik əmsalları, eləcə də bu əmsallara əsasən aktivliyin qiymətləri təyin edilmişdir.

Açar sözlor: tarazlıq, amsal, ekstraksiya, komponent, tanlik, aktivlik, selektivlik.

\section{ОПРЕДЕЛЕНИЕ КОЭФФИЦИЕНТОВ ИЗБИРАТЕЛЬНОСТИ И МАССОПЕРЕДАЧИ В ЖИДКОФАЗНОЙ ЭКСТРАКЦИИ ДЛЯ СИСТЕМЫ БУТИЛГЛИКОЛЬ-ВОДА-ИЗОПРОПИЛОВЫЙ ЭФИР}

\section{А.А.Гасанов}

Рассмотрены проблемы равновесия фаз, равновесное распределение компонента между фазами и определен коэффициент распределения в двух вариантах. Получены формула для определения коэффициента избирательности, уравнения, связывающие составы сосуществующих фаз путем приравнивая активностей в этих фазах, найдены константы Маргулеса. На основе заданного содержания компонентов находили численные значения $A_{A S}$ и $A_{5 A}$ (первый индекс относится к компоненту, второй - к компоненту, из которого, в основном состоит фаза). С помощью уравнения Маргулеса для тройных систем определены коэффициенты активностей компонентов А и В в двух фазах. Приведены экспериментально полученные значения мольных долей каждого из трех компонентов, отвечающие различным точкам бинодальной кривой, соответствующие коэффициенты активности компонента В, а также по этим коэффициентам рассчитаны величины активности.

Ключевые слова: равновесие, коэффициент, экстракция, компонент, уравнение, активность, селективность. 